Article

\title{
Who Can Speak? Rancière, Latour and the Question of Articulation
}

\author{
Iwona Janicka
}

Aarhus Institute of Advanced Studies, Aarhus University, 8000 Aarhus, Denmark; i.janicka@aias.au.dk

Received: 14 July 2020; Accepted: 12 September 2020; Published: 20 October 2020

\begin{abstract}
In recent years, scholars in broadly considered posthumanities have attempted to reconceptualize politics in order to better account for the role of nonhuman entities in political processes. In this context, the article instantiates a dialogue between Jacques Rancière and Bruno Latour on one of the fundamental questions of politics, that is, the question of logos. Even though Latour and Rancière differ considerably in their theoretical and political orientations, each of them revisits the question of 'who can speak?' in order to examine the ways in which speechless entities gain a voice, thereby becoming intelligible as political entities. In this article, I confront Rancière's reservations about nonhumans as political agents, showing how Latour offers pathways beyond Rancière's apparent bias towards the human, a bias that is, I argue, fundamentally contradictory to the latter's broader conceptualization of politics as aesthetics. I formulate a Latourian rebuttal of Rancière's reservations and analyse the utility of Latour's thought in overcoming Rancière's limitations. Latour's reorientation of logos towards the concept of 'articulation' makes it possible to evacuate, to some extent, the human exceptionalism from Rancière's philosophy. Combining Latour with Rancière permits to fundamentally rearticulate the parameters of left-wing thinking about nonhumans.
\end{abstract}

Keywords: Latour; Rancière; articulation; modes of existence; Greimas; nonhumans; politics; practice

\section{Introduction}

Who can speak? This question has been at the heart of politics since Aristotle's definition of humans as fundamentally political animals: a human who possesses logos is a political being. Jacques Rancière and Bruno Latour revisit this question again in order to explore, on their own philosophical terms, the ways in which speechless and invisible entities gain a voice, thereby becoming intelligible. Both thinkers focus on concrete practices to discern effectively the processes of visibilization and invisibilization (i.e., the ways in which entities are made intelligible, or are actively disregarded) that are operative in a given society. I employ the active forms 'to visibilize' and 'to invisibilize', rather than the more passive expressions such as 'being visible' and 'being invisible'. This is to emphasize the fact that there are active processes at play that render certain entities imperceptible; it is not the case that such entities are literally unseen or integrally unseeable. These often obscure processes must be uncovered and investigated, because they regulate who is allowed to be been seen and heard in moments of political and social crisis. In this way, they are politically crucial: they regulate the potential for transformation of the status quo. By turning to the terminology of intelligibility and visibilization-instead of virtuality, the theme of this special issue - this article aims at reframing questions of the virtual and the arts in the posthumanities. Much important scholarship has been produced on the intersection between virtuality and the posthumanities, particularly with careful attention to Gilles Deleuze and Félix Guattari's work. ${ }^{1}$

1 See, for instance: (Braidotti 2018, 2019; Hayles 1999; Massumi 1998, 2002, 2014; Colebrook 2014; Van der Tuin and Dolphijn 2010; Dolphijn and Tuin 2012). 
Whilst this article contributes to that conversation, especially strands focusing on politics, it does so by positing theoretical alternatives to the Deleuzian-Guattarian framework in which the posthumanities (broadly considered) are often framed. It proffers one such alternative, by considering Latour, Rancière and articulation.

This article instantiates a dialogue between Rancière and Latour on the question of logos. Readers familiar with both Rancière and Latour's work may well find this combination a somewhat curious choice. At first glance, they seem like worlds apart; their avowed political positions, philosophical interests, and personal trajectories are radically different. Latour, for instance, has been classified as a conservative, right-wing, neoliberal philosopher, who considers politics in terms of power struggles. He focuses on institutions and turns to traditional governmental forms-the parliament, the constitution, the republic -in order to think through the nature and the infrastructure of politics. Rancière, by contrast, is a radical left-wing thinker, who theorizes politics by attending to the ruptures evident within the usual way of doing political business. He is interested in how politics is renewed by those who have been officially excluded from its purview: slaves, women, proletarians. He analyses how institutions and traditional governmental forms are broken up and reconfigured by subjects typically denied their own voice. By consequence of such evident differences of opinion, there has been little critical discussion as to whether and how these two philosophers could be fruitful to each other's thinking before now. This article rectifies this lacuna, operating from the stance that there are good reasons to combine the pair's theories, despite superficial signs to the contrary. Attending to Rancière's and Latour's answers to the key political question, 'who can speak?', permits an exploration of the extent to which nonhumans can convincingly be considered as possessing logos. This is important in the context of recent technological and ecological developments: it allows us to trace the very conditions of possibility subtending the consideration of nonhumans as actors in political subjectivation. This task, however, is more straightforward in Latour than in Rancière.

The question of logos - that is, of who can speak-is central to Rancière's concept of politics. Rancière follows Aristotle's definition of human beings as political animals, proclaiming that '[a]ll political activity is a conflict aimed at deciding what is speech' and what is 'mere growl' (PL 4). ${ }^{2}$ In his work, Rancière shows how the Aristotelian political animal is divided from the very beginning. According to Aristotle, human beings are defined as political because they possess logos. Crucially, however, not all humans are considered to have logos. There are those who possess logos (and thus are fully human) and those who merely understand it but do not possess it (semi- or quasi-humans). Rancière demonstrates how this primary contradiction is constitutive of politics: politics is always dissensual with regard to the question of who can speak, that is, of who has the ability to produce speech rather than noise. He traces throughout history how logos is distributed unequally among human populations. The history of social movements shows a constant expansion of who is allowed to possess logos. This process, for Rancière, does not merely entail the inclusion of previously excluded entities into the logos club, as it were. Rather, it involves a radical reconfiguration of the criteria according to which some entities are (re)classified as speakers, whilst others are denied such privileges. Who does and who does not count constitutes, as Rancière puts it, a 'distribution of the sensible' (le partage $d u$ sensible). True politics happens in moments when those entities that did not count previously, the voiceless sans part in Rancière's terminology, access logos, thereby becoming intelligible (and visible) in a process of political subjectivation-and ultimately transforming the status quo. ${ }^{3}$ For this reason, Rancière considers politics as aesthetics, that is, as a force that revolutionizes how we

2 Rancière's works are abbreviated in the following way: AU—Aesthetic Unconscious (Rancière 2010a); BF-Bords de la fiction (Rancière 2017); D—Disagreement (Rancière 1999); DIS—Dissensus (Rancière 2010b); FI—Future of the Image (Rancière 2007); M-Method of Equality (Rancière 2016); MS—Méthode de la scène (with Rancière and Jdey 2018); PA-Politics of Aesthetics (Rancière 2013); PL-Politics of Literature (Rancière 2011).

3 See, in particular, Rancière's Disagreement and Politics of Aesthetics on the 'distribution of the sensible' (le partage du sensible) and the sans part. 
perceive the world. Politics is a transformative power that redistributes intelligibility and visibility in the world in a new way. ${ }^{4}$

In such a theoretical framework, the central challenge becomes: how to recognize signs of presence or absence of logos in an entity? What allows us to say that logos is intelligible in one form (or embodiment) but not in the other, without turning to essentializing narratives dependent upon an entity's inherent capacities such as reason, sentience, life (or lack thereof)? In interviews, Rancière has often been asked point-blank whether it is possible to include nonhumans in his concept of politics. ${ }^{5}$ This follows logically from his philosophy, particularly from his contention that the ultimate question of politics relates to who is considered a legitimate subject of politics and who is not. Clearly, this is inextricably connected to the question of 'who can speak?'. Yet Rancière refuses to consider nonhumans as politically viable sans part. So doing, he draws a hard line between nonhumans-such as animals, plants, environment, artificial intelligence, etc.-and humans. By excluding nonhumans from politics, Rancière seemingly rehearses the limiting exclusionary gesture that he himself identifies, and critiques, in Aristotle. He resituates, but does not subvert, the Aristotelian demarcation between beings of logos and beings of no logos, ending up in the borderlands of the anthropomorphic.

In this article, I confront Rancière's reservations about nonhumans as political agents, showing how Latour offers pathways beyond Rancière's apparent bias towards the human, a bias that is, I argue, fundamentally contradictory to the latter's broader conceptualization of politics as aesthetics. We start with a series of citations from Rancière that problematize the inclusion of nonhumans into politics. These quotes refer explicitly to Latour's position on nonhumans as legitimate political actors and show Rancière's terms of engagement with Latour. The rest of the article focuses on Latour's own approach to the question of 'who can speak?', comparing his affirmative paradigm for nonhumans as political entities with Rancière's human-centered framework. Ultimately, I formulate a Latourian rebuttal of Rancière's reservations, analysing in tandem the theoretical value of the critical encounter at hand. What becomes clear is the utility of Latour's thought in overcoming Rancière's limitations. Latour's reorientation of logos towards the concept of 'articulation' makes it possible to evacuate, to some extent, the human exceptionalism from Rancière's philosophy. Situating Rancière and Latour as productive, if combative, interlocutors, this article aims to open up Rancière's thought and his radical left-wing politics towards the inclusion of nonhumans-whilst concomitantly shifting, however slightly, the Left's disposition towards Latour. This unexpected combination, then, permits the temporary suspension of the usual divide between the Left and the Right in order to fundamentally rearticulate the parameters of left-wing thinking about nonhumans (cf. Schultz and Latour 2020; Latour et al. 2019).

\section{Rancière's Critique of Latour}

The Method of Equality (M) (2016), an anthology of Rancière's notable interviews, foregrounds Rancière's development as a thinker on a host of topics, including environmental philosophy, and in particular, the potential similarities between Rancière's own philosophy and that of radical political ecology. Asked directly about his opinion on Latour's attempted 'political subjectivation' of nonhumans, Rancière distances himself explicitly from any possible recuperation of his ideas within posthumanities, broadly understood:

There is a decisive point of difference for me. Politics has always been defined in terms of a polemic about the human, about the distribution of human groups, the capacities they're acknowledged to have, about the capacity for speech they're granted. Politics for me has

4 I use 'intelligibility' and 'visibility' interchangeably in this article, as both Rancière and Latour understand visibility and visibilizing procedures in terms of intelligibility and making intelligible. Both avoid the terminology of recognition (Anerkennung) in order to emphasize the necessary changes in the very terms through which visibilizing processes are enacted.

5 See his Method of Equality (pp. 162-64; discussed below in detail); and Bennett (2010, p. 106). 
always played out around these questions: are these humans true humans, do they belong to humanity, or are they semi-human or falsely human? (M 162)

Rancière unequivocally limits politics to human entities only. The human-nonhuman divide is the hard limit that Rancière poses in his conceptualization of politics. He identifies substantive reasons for the necessary limitation of political agency to humans only:

I don't think you can have politics without the possibility of subjectivizing 'the part of those that have no part' [la part des sans-parts]. Subjectivation happens through a declaration that reconfigures the division between human beings. [... ] The representatives of animals, of nature, of the Earth, and of things, are always going to be humans, which means human interests. (M 162-63)

The key question is then political subjectivation. For Rancière, nonhumans cannot be political subjects because they are not capable of 'self-declaration' (autodéclaration) (M 164). And 'self-declaration' is what makes politics possible because this, at the end of the day, is what gives legitimacy to any form of representation. What's more, the problem for Rancière is that nonhumans cannot represent their own interests. It is always humans that pick up on professed nonhuman interests to make intelligible their own stakes; this kind of veiled instrumentalization is problematic. Rancière continues:

I don't think we humans can define subjectivization for non-humans, or otherwise we are necessarily going to give people the capacity to represent things. When Latour says 'we represents humans, and we represent things every bit as much', the difference is nonetheless that humans can challenge those who represent them, like the Indignant of Madrid [movement] who said 'you don't represent us'. Things, wolves or sheep, can never divest humans of the representativeness they've given themselves. (M 164)

For Rancière, then, the bottom line is that nonhumans cannot oppose what is done to and said about them. They do not have the means to resist as they do not possess their own voice that could be turned into speech $(\log o s)$. To some extent, they are entities that are petrified in their position of no logos, of eternal (and eternally unintelligible) noise. Nonhumans will never be able to exit this state; as such, they serve as the ultimate limit against which human beings can define themselves. To what extent can nonhumans articulate dissensus, and to what extent can they represent themselves? This is the question Rancière poses in terms of Latourian politics, one that is addressed throughout this article.

Rancière's concern about including nonhumans in his vision of politics is connected to his philosophical and political roots-namely Marxism and Althuserrianism - that makes it difficult for him to welcome nonhumans with open arms into his politics. ${ }^{6}$ Yet it is important to acknowledge that his reluctance is also of a practical, even arguably activist, nature. Such resistance, I argue, reflects Rancière's attempt to save politics by not letting political practice dissolve into vague notions that sound good but have little operative power in practice. It is for this reason that he is so critical of Gilles Deleuze's understanding of politics, and Jacques Derrida's idea of 'democracy to come'. Rancière claims that, in Derrida, 'what disappears is democracy as a practice' (DIS 59). Both Derrida and Deleuze, according to Rancière, suffer from a lack of specificity in their politics (cf. MS 32). Rancière's wariness is particularly noteworthy as Deleuzian and Derridian conceptualizations of politics have been fundamental to a wide range of posthumanist and neo-materialist re-formulations of politics in recent years. ${ }^{7}$ I agree with Rancière: thinking about politics as separate from concrete practice is problematic. Such a separation is, to my mind, potentially self-sabotaging, ultimately rendering politics impotent by neutralizing its potential for social transformation. Any serious effort to consider politics and nonhumans together must, therefore, reflect on political practice (cf. Janicka 2017, 2020). At the same time, I maintain

6 See Hornborg (2017) for a critical view of posthumanism from a Marxist perspective.

7 See, for instance: (Braidotti 2013; Bennett 2010; Massumi 2014; Coole and Frost 2010). 
that precisely because of Latour's strong focus on practice, he might be one of the few thinker in the posthumanities, broadly understood, that can fruitfully be brought into dialogue with Rancière and, so doing, with left-wing political thought more generally. Practice is a crucial connecting node between Latour and Rancière, at the forefront of the pair's otherwise disparate thought.

A point of clarification before we proceed further. The aim of the present article is not to turn nonhumans into humans (or vice versa), and, so doing, homogenize various entities into a generalized kind of flat ontology. The argument is not that there is no difference between humans and nonhumans. Instead, I maintain that we must acknowledge our unexamined biases and lapses in critical judgment in terms of who or what we consider to be capable of political subjectivation. The plebeians at the Aventine Hill in 5th century BC offer the paradigmatic example of Rancière's approach. These subjects were considered incapable of speech by the higher-status patricians and, as such, were classified as beings that were on the same level as beasts. They were considered nonhuman. Plebeians, as Rancière himself argues (D 23-35), were turned into political subjects through a polemical reconfiguration of the distribution of the sensible. Yet Rancière never questions the strict distinction between beings of logos and beings of no logos in contemporary society, in contrast to his rigorous historical analyses. Rancière's shortcomings on this front opens up a space for reflection on entities that are considered incapable of logos from within our twenty-first century distribution of the sensible. Unlike Rancière, we do not have the benefit of temporal distance in our analyses, a distance which has allowed him to 'return' Roman plebeians to logos fairly easily. I say 'fairly easily' because, viewed from the perspective of our present distribution of the sensible, plebeians have always already been in the possession of logos. It is in this context, then, that Latour's perspective on 'who can speak' will help us to rethink, and move beyond, the superficially hard line that Rancière establishes between beings of logos (exclusively humans) and beings of no logos (all nonhumans).

\section{From Aristotle to Greimas}

The prominence of Aristotle is the major difference between Rancière and Latour's approach to the question of logos. Whilst Rancière considers Aristotle a touchstone, the Greek philosopher is not at all an important reference point for Latour in thinking politics. Indeed, Latour unapologetically admits: 'I do not believe that returning to Aristotle is helpful' (TAP 814). ${ }^{8}$ Despite such explicit distancing from the Aristotelian legacy, Latour does not avoid the question of logos, given its centrality to many political theories. Rather, he tackles it head-on and, somewhat provocatively, claims actually to be contributing to the tradition of the Aristotelian 'political animal' (cf. PN 71). This serves the aim, however, of overcoming the prohibition on 'the exploration of new speech prostheses' (PN 71): 'I am indeed situating myself in [ ... ] the long and venerable tradition that has constantly extended what was called humanity, freedom, and the right of citizenship. The story is not over' (PN 71). Instead of Aristotle, Latour turns to the pragmatists, especially John Dewey, and semioticians, notably A. J. Greimas, to provide the underlying theoretical support for his own conceptualization of politics. Latour responds to the same question as Rancière-'who can speak?'-but from within a heterodox version of structural semiotics. As we will see, this shift is crucial for the kind of answers he is able to provide.

If we translate Rancière's central political question-how to distinguish speech from mere growl?-into a Latourian framework, then the heart of the problem lies in the questions of signification. What is meaning? How is meaning produced and sustained? Who is the designated carrier of meaning? What, then, is logos in Latour? First of all, logos is not something that only humans are capable of possessing: 'speech is no longer a specifically human property, or at least humans are no longer its sole masters' (PN 65). Instead, logos is a property of heterogeneous, human-nonhuman

8 Bruno Latour's works are abbreviated in the following way: AIME: An Inquiry into Modes of Existence (Latour 2013a); DE-Down to Earth (Latour 2018); FG—Facing Gaia (Latour 2017); MC-On the Modern Cult of the Factish Gods (Latour 2010); PH-Pandora's Hope (Latour 1999); PN-Politics of Nature (Latour 2004); RS—Reassembling the Social (Latour 2005); TAP_'Turning around Politics' (Latour 2007); WAP_'Well-Articulated Primatology' (Latour 2000); WNM-We Have Never Been Modern (Latour 1993). 
assemblages. Latour thus redistributes the capacity for speech and sense-making between humans and nonhumans (cf. PH 141). Latour's contention that not only human beings can speak is made possible by Greimassian semiotics, with its central assumption that the production of meaning is, first and foremost, an activity of translation. This implies that signification is not static -as in: a presence in a text or a special capacity wielded by a human being at will—but, rather, that it emerges in the dynamic process of transformation. Secondly, logos can only be discerned by tracing a metamorphosis of one form into another. Signification is a transposition of one system of signs into another system of signs, it is, in other words, grounded in the possibility of transcoding (Greimas 1990, p. 7). This also suggests that the way in which signification is distributed among beings in the world is not attached to their specific identity (their being fully human, in this case) but rather it is tied to the place and the role these beings play in the operation of translation. Semiotic activity is not only restricted to humans and their interaction with the world but operates across a wide variety of nonhuman entities. Notably, semiosis is possible with or without the presence of humans, as is argued in biosemiotics. The ultimate challenge in this framework is-we might say-technical, in the sense that it is a question of finding the right tools and techniques to capture the strands of signification and transcode them.

Latour's approach to the question of logos is fundamentally determined by this Greimassian framework. Translatability is crucial here, as 'one of the fundamental properties of semiotic systems' (Greimas and Courtés 1979, p. 398). ${ }^{9}$ If, as Greimas claims, signification lies in the very 'possibility of the transformation of meaning' (Greimas 1990, p. 9), then this, in Latour's thought, requires the involvement of many different entities and processes. This is also why Latour underlines that speech is always mediated through other beings, epistemological frameworks, infrastructures, techniques and devices - and, thus, it cannot be a property of humans alone. As he puts it: 'I do not claim that things speak "on their own", since no beings, not even humans, speak on their own, but always through something or someone else' (PN 68, emphasis in the text). Processes of signification-that is, ones producing speech rather than noise-are therefore inseparable from processes of mediation and transcoding. This is what, following Greimas, Latour calls 'translation' in his work, and what constitutes one of the key concepts of his politics. In Greimassian semiotics and in Latour's heterodox version thereof, to speak is simultaneously to translate and to produce signification (cf. Latour 2014).

Admittedly, Rancière is not entirely insensitive to the questions of mediation, even though he does not express it in these terms. It is arguable, even, that mediation drives his philosophical project to some extent. When Rancière claims, for instance, that 'the logos is never simply speech, because it is always indissolubly the account that is made of this speech' (D 22-23, emphasis in the text), he points to the structures in place that enable some voices to be amplified while others are suppressed. An encounter between two interlocutors is never unmediated, but passes through webs of sedimented social and historical meaning. Signification never reaches the other directly; it is always filtered through other entities. Yet, Rancière does not consider any concrete devices, techniques, infrastructures or procedures that determine such processes of hearing or not hearing, seeing or not seeing. Discussion of such topics may have potentially broadened his conceptualization of the role that nonhumans play in processes of signification, as evident in Latour's work. Instead, Rancière's chosen theoretical framework forecloses this path. Greimassian semiotics, by contrast, facilitated an opening in Latour that other frameworks, including an Aristotelian one, would most likely have precluded. Semiotics cleared the way for hearing nonhumans speak.

\section{Latour on Articulation}

In light of this context, the question for Latour becomes: how does one make beings speak? There is always a danger of either uncontrollable chatter or complete muteness-something that

9 Translation from (Perron 1988, p. xix). 
Rancière has also identified in his reflections on literature (AU, FI, PL, PA, BF). The challenge, then, is to find ways that permit and provoke nonhumans to speak in a meaningful way, as Latour asserts:

Each discipline can define itself as a complex mechanism for giving worlds the capacity to write or to speak, as a general way of making mute entities literate. It is odd, then, that political philosophy, so obsessed with its own logocentrism, did not see that the greatest share of the logos was to be found in laboratories. Let us remember that nonhumans are not in themselves objects, and still less are they matters of fact. They first appear as matters of concern, as new entities that provoke perplexity and thus speech in those who gather around them, discuss them, and argue over them. (PN 66, emphasis in the text)

Latour suggests here that there are two stages at play to make nonhumans speak. Firstly, such entities generate a problem, a 'perplexity', that makes humans around them speak to each other. Secondly, nonhumans respond to humans provided that the 'right questions' are posed to them. ${ }^{10}$ The task, then, is to create conditions of possibility in which an entity can become intelligible, ask humans (and others) its own questions in its own terms and, ideally, change the terms of the exchange itself.11 This is what Latour calls 'articulation' (cf. PN 141). For Latour, entities are not by definition either mute or capable of speech. Rather, they are better or worse articulated in a particular setting. Latour develops a panoply of techniques, protocols, conceptual tools and technical devices to register these articulations in his An Inquiry into Modes of Existence (2012/2013) (AIME). Articulation is applicable as a term to all possible kinds of nonhumans as well as humans. And for this reason, it is the underlying conceptual grid and 'the ontological foundation of AIME':

Articulation is not a property of human language but an ontological property of the universe. The question is no longer whether or not statements correspond to a state of affairs, rather whether or not propositions are well articulated. (Latour 2013b)

Articulation becomes a relatively common characteristic, applicable to all kinds of entities (cf. PH 142). Logos operates in an already articulate and articulated world. As such, there is no need for Latour to position nonhumans within the dichotomy of speaking vs mute beings from within which Rancière operates. The distinction that is important to establish is between the different regimes of enunciation in which entities articulate themselves or, in other words, between different modes of existence. ${ }^{12}$ For Latour, 'to be' and 'to signify' are synonyms. Beings can therefore never be defined in terms of self-identity, as being-qua-being, but instead they need to become articulate by passing through other entities:

Entities are not dumb, rather they are articulated; we do not speak because we have language but because we conspire with, and participate in, this generalized articulation. It is the articulation of beings that enables us to talk about them. (Latour 2013b)

This means that if humans speak, it is because nonhumans already speak, in infinitely multiple languages: it is nonhumans that brought humans into existence as speaking beings. In an already articulate world, humans orient strings of articulation, transcoding them to render them intelligible to themselves and to each other. Humans do not 'give meaning' to nonhuman entities as such or 'interpret brute matter', but rather they create favourable conditions in which nonhuman entities become visible. In order to do that, however, nonhumans and humans alike require a set of devices, gestures, settings, procedures, instruments, trials and sites. They need the right infrastructure to capture and amplify

10 On posing the 'right questions', see the work of Vinciane Despret that has influenced considerably Latour's thinking: Despret $(2004,2008,2016,2019)$ and a special issue of Angelaki on Despret (Buchanan et al. 2015)

11 See, on this: Latour[1997] (2006), where he discusses Stengers (2010) 'recalcitrant subjects'.

12 'Regimes of enunciation' is an earlier term for 'modes of existence'. They are used interchangeably (cf. MC 100; Latour 2012, p. 562). 
their speech that would also be proper to their mode of existence. In the case of the natural sciences and a scientific mode of existence, the laboratory provides the felicity conditions for some nonhumans to speak. As Latour claims, 'we are allowed to say new, original things when we enter well-articulated settings like good laboratories' (PH 144). 'Well-articulated settings' are ones that provide the right conditions for an entity to express itself in a form that would best capture its mode of existence in the world. Humans and nonhumans in such well-articulated settings attain existence together as both are plagued by existential incompleteness.

In order to exist and subsist, humans and nonhumans alike need to be constantly maintained, renewed, remade or, as Etienne Souriau puts it, 'instaured' (Souriau 2015; Stengers and Latour 2015). Articulation 'goes much deeper than speech' (PH 144) because, as a concept, it is able to capture a whole panoply of regimes of enunciation that are shared by a wide range of entities, both human and nonhuman. It also emphasizes that humans and nonhumans are all in need of support in order to become intelligible. From this perspective, Aristotle's logos-bearing human-a male, able-bodied citizen of possessions-does not, in fact, speak independently, despite professed assurances of autonomy. Even the nominally archetypical figure of logos, an upright (physically, socially, ethically) speaking figure $^{13}$, had to construct the right infrastructure to constantly renew and sustain its intelligibility. This has been effectively achieved down through the ages, becoming sedimented in social structures, practices, architecture and artefacts. Such infrastructure operates according to a double gesture. On the one hand, it repeatedly instaures this figure of logos and ensures its intelligibility, whilst, on the other hand, it invisibilizes its operations, making this subject seem natural and a priori constituted. Feminist, queer and postcolonial scholars have all analysed and critiqued different aspects of the constant process of instauration governing this figure, and interrogated the apparent 'naturalness' of its operation by attending to other logos-bearers. Rancière problematizes this figure in his critique of Aristotelian logos. Nevertheless, he tacitly assumes that the category of the human does not need to be constantly instaured against the category of the nonhuman. The human, however, is also in perpetual need of (re-)instauration.

Let us return to the topic of modes. Whilst processes of instauration operate through modes, not all modes are equally suitable for rendering all beings intelligible. We can only speak about entities in accordance with the mode in which we engage with them, and through which they reveal themselves to us. This is because different modes register different practices and so trace specific trajectories based on an entity's activity and relationality, rather than on its inherent substance. This is where posing the 'right questions' is of critical importance. With reference to the work of Vinciane Despret, Latour claims that 'we are allowed to speak interestingly by what we allow to speak interestingly' (PH 144, emphasis in the text; Despret 1996). This means that the process of articulation has to be active on both sides-human and nonhuman-in order to be successful and, in the context of the scientific mode of existence, to produce good science. It needs, for example, to extend to nonhumans the possibility to generate new problems, thereby imposing new obligations on the scientist (WAP; Latour[1997] 2006; Stengers 2010; Despret 2004). Without some form of cooperation from nonhumans, scientific investigation would be impossible (Despret 2013; Porcher 2017).

What's more, many beings operate in multiple modes. This, according to Latour, makes it possible to describe the co-present modes but, at the same time, makes it challenging to disentangle them from one another. In this context, the category of human language, just like the category of society, is not considered helpful: it cuts across a whole range of phenomena without sufficient attention to the specific practices that bring entities into existence, an existence which is, in the first place, only conceivable through modes. In Latour's framework, therefore, it is impossible for an entity to 'simply be'; it is impossible for an entity to be, by definition, an entity of logos independently. An entity exists only through various modes and through other beings. It exists, to borrow Etienne Souriau's

13 See Cavarero (2016) for critique of the upright speaking figure. 
phrasing once more, only 'through the strength of others' (Souriau 2015, p. 130). For Greimas, Latour, and Souriau, metamorphosis of form - a translation - is fundamental in establishing and sustaining an existence. Souriau's Different Modes of Existence (1943/2015) is, as Latour admits, 'a close relative to the inquiry into modes of existence' that he himself has been pursuing for more than three decades (Stengers and Latour 2015, p. 11, note 2). Latour would no doubt concur with Souriau's claim that 'in order to exist, each being must discover its mode of existence (or else we must discover its mode of existence for it)' (Souriau 2015, p. 181). This also means that 'there are still unnamed and unexplored modes of existence, yet to be discovered for the instauration of certain things, which will go unheeded until such a time as the necessary mode will have been invented, innovated' (Souriau 2015, p. 181). The visibilization of certain entities becomes a constructive and cooperative venture brought about through an interplay of humans, nonhumans and available infrastructures (technical, conceptual, social, etc.). And this is only possible by establishing relevant, collective and effective practices.

The challenge, then, is how to make a new entity articulate, or in other words, how 'to make new phenomena visible' (PH 143). For Latour, this is possible by the identification of concrete differences that distinguish one articulation from another (PH 143). Becoming 'more articulate' (PH 144) means for an entity to become 'something that is being made up of many more items, many more articles [... ] many more reactions to many more situations. There are, quite simply, more and more things to say about it' (PH 143-144). In this way, an entity stops being 'mute, unknown, undefined' (PH 143). This is, of course, not easy and Latour suggests that one needs to invent 'tricks' to make nonhumans talk, that is, to make them 'offer descriptions of themselves, to produce scripts of what they are making others-humans or non-humans-do' (RS 79, emphasis in the text). Much of Latour's Actor-network Theory (ANT) has been devoted to triggering these instances of visibility. This has been attempted in multiple ways. First, by studying innovations and controversies in sciences, as these instances could be 'maintained longer as visible' due to their complexities, complications and recalcitrance (RS 80). Second, by taking distance from the objects of study: 'distance in time as in archaeology, distance in space as in ethnology, distance in skills as in learning' (RS 80)—as was necessary for Rancière's work. Third, by analysing accidents, breakdowns and strikes, where 'risky' objects create possibilities to 'hear, see, and feel what objects may be doing when they break other actors down' (RS 81). Fourth, by turning to historical reconstruction, 'using archives, documents, memoirs, museum collections, etc., to artificially produce, through historians' accounts, the state of crisis in which machines, devices, and implements were born' (RS 81). This allows us to appreciate the fragile and risky nature of all inventions. And, finally, by turning to fiction, and specifically science-fiction, to generate visibility through proposing alternative narratives and alternative worlds (RS 82).

With the heuristic of articulation and visibilization, AIME becomes a broader intervention in philosophy and semiotics, not the least because it encompasses a wide variety of practices in which science is but one of many modes. Critical to AIME's more general utility is the way in which it affords a macro-level perspective. In this way, it allows a movement from the specific minutiae of concrete examples-that could always be considered exceptions or special cases-to the relevant abstracts, 'zooming out' to reveal patterns that link specific practices despite apparent differences. Latour problematizes the fact that science has been a dominant form of identifying nonhumans but he, nonetheless, admits that science has been extremely skilled at establishing dialogues with such entities. The challenge most forcefully expressed in AIME, then, is to catch up on developing protocols and devices that would capture human-nonhuman collectives beyond the scientific mode: religion, technology, morality, organization, metamorphosis, fiction, and so on.

\section{Representation, Human Interests, and Anthropocentrism}

Both Latour and Rancière are preoccupied with how reality is made visible, how entities become intelligible. In the case of nonhumans, the 'visibilizing' procedures that Latour proposes arguably focus on human agency. Humans trigger visibility for nonhumans in specific settings, like scientific laboratories, in order to advance their own interests. Nonhumans do not emerge by themselves. They are constantly 
accompanied and supported in their emergence by human helpers. And we must acknowledge that this is correct, at least to some extent. However, we must equally acknowledge that the same holds true for humans. They also need alliances and they need to 'pass' through other beings, human and nonhuman, to become intelligible. Marked subjects, i.e., those that do not represent universality due to their gender, race, sexuality, age or physical ability, in particular need to build a robust infrastructure for triggering and sustaining their intelligibility. Even Aristotle's being of logos, as I argue above, has had to establish 'visibilizing' procedures in order to assure a constant renewal of himself as a universal human being.

Rancière accuses Latour of representing veiled 'human interests' rather than the interests of things, animals, nature and earth, pointing out that neither sheep nor wolves can dismiss human representation (see earlier block quote; M 163). A Latourian perspective, however, offers several rebuttals to this contention. In the first instance, there is no possibility for us, as humans, to move beyond our semiotic perspective. We are only able to register differences that are relevant, that is, meaningful, to us. We do not have the means to perceive nonhuman semiosis without immediately transcoding it to human signification. We constantly develop protocols and tools to capture the new invisibles. Yet, in our interaction with the world, the only beings that exist for humans are entities that humans are capable of decoding. Without signifying, beings cease to exist. Some of these nonhuman entities will become intelligible to us only under the condition that we find a way to pose them the right questions. Seen from this perspective, a semiotic, Umwelt-determined anthropocentrism is inevitable. And it is for this reason that, in his recent work, Latour positions himself with respect to anthropocentrism, and the related question of politics, in the following way:

[T] here is no politics other than that of humans, and for their benefit! This has never been in question. The question has always been about the form and the composition of this human. What the New Climatic Regime calls into question is not the central place of the human; it is its composition, its presence, its figuration, in a word, its destiny. Now if you modify these things, you also change the definition of human interests. (DE 5.400-01 [chp. 18])

Latour claims that the term 'human' has been in constant oscillation between two poles, conceived on the one hand as a natural being (as part of the natural world), whilst, on the other, as being that is capable of putting itself outside or above the nonhuman environment through logos, reason, soul or culture. Consequently, the question as to the centring of the human within philosophy has, according to Latour, been incorrectly posed. A false dichotomy between nature versus human has been established: human beings can either remain at the centre, or exit their semiotic framework by entering the world of nature and dissolving into it. The framework of anthropocentrism is problematic for Latour because, first, it assumes that there are two mutually exclusive positions that we are compelled to choose between; and, second, that these positions themselves have very precise boundaries. Once we choose one option-either anthropocentrism or ecocentrism-then it is presumed that whatever remains would fall into an outside. That it would become irrelevant, unconnected and unimportant. However, for Latour, there is no great outside anymore. ${ }^{14}$ It is not, therefore, a question of decentring the human, but rather of recomposing the human, of constantly translating the human in concert with different nonhumans. Latour proposes changing our terminology from 'humans' to 'terrestrials (the Earthbound)', which, quite conveniently, does not specify species, and so bypasses the linguistic problem of anthropocentrism: 'Saying "We are earthbound [terrestres], we are terrestrials amid terrestrials," does not lead to the same politics as saying "We are humans in nature."' (DE 5.407 [chp. 18]). Our task becomes finding out how many other beings we need so that we can 'subsist' (subsister). By drawing up a list of these entities, 'terrestials' would be able to create their 'dwelling place' (terrain de vie) (DE 5.409 [chp. 18]). For Latour, this is a dissensual process in which conflicts of interest and interpretation between overlapping agents, human and nonhuman, are integral part.

14 Here, Latour agrees with Peter Sloterdijk's analysis in Spheres (Sloterdijk 2011, 2014, 2016). 
The aim is not to reach a consensus but rather to expose oneself to a steep learning curve with regard to our undeniable dependence on nonhumans.

As to Rancière's question regarding representation: Latour argues for the practical necessity of anthropomorphizing nonhumans, or even personifying them, in order to be able to take them into account. Indeed, this is expressed in his more recent work:

The fiction resides not in giving water a voice but in believing that one could get along without representing it by a human voice capable of making itself understood by other humans. The error does not lie in claiming to represent nonhumans; we do that in any case all the time when we talk about rivers, voyages, the future, the past, States, the Law, or God. The error would lie in believing it possible to take such interests into account without a human who embodies, personifies, authorizes, represents their interests. (FG 273, emphasis in the text)

For Latour, translation between entities cohabiting in the world is fundamental. This constant translation between different entities and different modes of existence in the process of semiosis involves transcoding nonhumans into human signification so that nonhumans can be taken into account as entities on their own terms. Nonhumans need to emerge to humans in moments of perplexity, crisis, sudden difference in patterns so that we can appropriately address and engage with them. However, this process is not unilateral. As asserted above, human beings are constantly translated, constantly instaured, with and through different humans and nonhumans. The process of engendering entities through translation operates in both directions. ${ }^{15}$ Intelligibility is created for both humans and nonhumans in a continuous process of instauration. The ambition of AIME's project can be understood, therefore, as the expansion of our basic sense-making mechanisms through more and more elaborate translation protocols in our engagement with nonhumans. This, by consequence, catalyses the emergence of more 'invisibles', ultimately reconfiguring our human semiosis and our place among other entities in the world.

Latour's unapologetic reclamation of anthropocentrism might seem somewhat discordant. For readers familiar with Latour's early work, it appears to all intents and purposes like back-pedaling on his more radical statements, especially those in which nonhumans are invested with more power and where 'democracy [is] extended to things themselves' (WNM 142). Latour is quite right: any clear dichotomy between anthropocentrism and non-anthropocentrism is conceptually challenging, because it requires an all-or-nothing approach in order to be consistent. The non-anthropocentric approach, to some extent, tacitly assumes that it would be possible to shed our basic semiotic framework, tied to our bodies and its epistemic situatedness in the world, and to make political and ethical decisions without any reference to human values. If we assume that this entirely disembodied position is neither desirable nor possible anymore, then we need to admit that we will always, inevitably remain anthropocentric. Nevertheless, strong pushback on this understanding of anthropocentrism is evident in current discussions about human exceptionalism. It is a bone of substantive contention in the vast literature on the subject of anthropocentrism. ${ }^{16}$ It is beyond the scope of this article to review this debate in-depth, but, briefly, many scholars in broadly considered political ecology, animal studies and critical posthumanities argue for non-anthropocentrism as an explicitly political and strategic position. They accept the semiotic, Umwelt-determined anthropocentrism, as I call it, but oppose the superiority of human beings over other beings. They distinguish, for instance, between inevitable and arrogant anthropocentrism (Gruen 2015)—put otherwise, between human-centredness and human self-centredness (Plumwood 2002)—where the former designates Umwelt-determined anthropocentrism, and the latter refers to humanism, human superiority or the paradigm of human exceptionalism.

15 Latour proposes the term 'engendering' as an alternative to production (see DE).

16 See, notably, the discussions on anthropocentrism in: (Plumwood 2002; Boddice 2011; Gruen 2015; Kidner 2014; Oliver 2007; Kopnina et al. 2018; Marchesini 2015; Crist and Kopnina 2014). For a useful overview of the debates from the perspective of animal studies, see: (Probyn-Rapsey 2018). 
Many non-anthropocentric positions postulate more connectedness with nonhumans. In this way, they are on the same page as Latour. They claim that nonhumans (more-than-humans, other-than-humans) are not outside in nature, surrounding the human, but instead constitute the very make up of human beings. This is the baseline of non-anthropocentrism. It is admittedly difficult not to agree with Latour's declaration that, because of our semiotic locatedness, 'there is no politics other than that of humans, and for their benefit' (DE 5.400 [chp.18]), and that our decisions will be pre-determined by human values. Nevertheless, the non-anthropocentric position is important because of its strategic radicality. What non-anthropocentric scholars are actually after, conceivably, is to prevent a situation where all ethical and political claims are trumped by a vision of a universal human being. That is, a being that is detached from their specific ecology of practices, their concrete environment with its concrete set of obligations, interests and stakes. Instead, they aim to draw attention to our embeddedness and dependence on a wide variety of nonhumans. This is where Latour and non-anthropocentric approaches to nonhumans overlap. Having said that, a significant advantage of Latour's position is, perhaps, that he has no aspirations to ethical purity, as is the case for some of the more radical non-anthropocentric positions, that could all too quickly lead to dogmatism and could be, in consequence, counterproductive. ${ }^{17}$ Influenced by Isabelle Stengers and Donna Haraway, Latour's work assumes that the relationship between humans and nonhumans offers no guarantees that the decisions we make are absolutely correct. There will always be entities that will be made unintelligible by our practices, and that will carry the brunt of the consequences. We are never absolved from doubt and hesitation. ${ }^{18}$ The aim of Latour's politics is, thus, to keep a space open to which invisibilized entities can return and reconfigure the distribution of the sensible (PN, AIME).

Finally, within the Latourian framework, entities must cooperate so that humans can demonstrate agency and, specifically, for science to take place. Indeed, such a reconfiguration of human power and agency-from autonomy to obligatory collaboration with nonhumans-is one of the sobering effects of Latour's work. In response to Rancière's claim that wolves and sheep cannot dismiss human representation, we find two Latourian rejoinders. First, nonhumans show resistance or, in Isabelle Stengers' words, 'recalcitrance' in terms of what can be done to them and how they can be represented, as Vinciane Despret aptly puts it in the evocative title of her book chapter, 'Sheep Do Have Opinions' (Despret 2005). Despret's work in ethology, which has considerably influenced Latour, provides a compelling counterargument to Rancière's stance on representation. Secondly, Rancière misrepresents Latour; the latter, in actuality, does not contend that humans and nonhumans can be equally well represented. Instead, he claims that, very often, it is nonhumans that are more carefully consulted than humans, asserting that: 'No one would dream of talking about elephants without consulting the said elephants by experimental procedures of unprecedented subtlety. With humans, though, we do not take so many precautions' (PN 170). Latour suggests that, similar to the noise made by nonhumans, even human subjects have difficulty in challenging interpretations of their behaviour advanced by classical sociologists studying them. The anger of 'farmers, the poor, fetishists, fanatics, priests, lawyers, and businessmen' (RS 99) has hardly ever been recorded, and so they were not in the position to 'bite back at the sociologists' proofs' (RS 98). ${ }^{19}$ Rancière's core argument as to representation, and specifically the misrepresentation of nonhumans, then, is on shaky ground, far less straightforward than he suggests.

The problem of representational equality for humans and nonhumans initially motivated ANT to move beyond the social explanations of traditional sociology. Whilst science seemed to be capable of representing nonhuman subjects carefully enough, human subjects were caught in narratives that ceased to account accurately for their place and agency within the world. In ANT, Latour pursued a

17 In this context, see, for instance, a discussion on the current state of the animal liberation movement in: (Cavalieri 2016).

18 On complicating innocence and moving away from the idea of purity in ethics, see: (Haraway 2008).

19 See also, on the problem of respondents' anonymity in sociological research, and the related issue of 'theorizing behind someone's back': (Despret 2018). 
'symmetrical' approach in the sciences, in order to provide a fuller picture of how human-nonhuman entanglements construct objectivity. Greimassian semiotics helped Latour to level the playing field, alongside enabling him to draw out the human aspect in natural sciences and the nonhuman aspect in sociology and political theory. This flattening allowed for beings to be assessed in terms of their potential to transform situations rather than their inherent quality. And it is in precisely this power-invizibilized entities' ability to radically change the intelligibility criteria of a situation —-that Latour's thought and Rancière's politics as aesthetics intersect productively.

\section{Conclusions}

In his book-length study of Rancière, Samuel A. Chambers maintains that the philosopher tacitly challenges Aristotle's anthropocentrism by pointing to the dissensual nature of logos (Chambers 2013, pp. 105-8). Evidently, I disagree. Indeed, I argue that Rancière in fact repeats Aristotle's limiting gesture with regard to nonhumans. Like many other philosophers before him, Rancière sets a limit between humans and nonhumans that is not to be crossed. Even though he problematizes this very distinction in Aristotle's work, arguing that it is precisely politics that allows us to draw the line between speech and noise, the question of logos nevertheless remains the ultimate frontier that marks, for Rancière, the difference between humans and nonhumans. In this article, I turn to Latour's concept of articulation to interrogate the extent to which it remains fruitful to retain this anthropocentric 'hard line'. Latour moves away from an idea of a purified human being-a naked and universal entity without attachment to or dependence upon anything because they are equipped with logos-and, instead, redefines humans as fundamentally composed of nonhumans, and we could add, reciprocally composed with nonhumans. This does not necessarily mean, however, that Latour rejects any differentiation between humans and nonhumans. ${ }^{20}$ Rather than establishing a single differential limit, such as logos, he emphasizes an expansive plurality of differences. The concept of 'articulation' makes this critical movement possible.

Latour offers Rancière a way to exit the paradox at the heart of latter's politics as aesthetics. Articulation allows us to overcome Rancière's deficiencies, namely his commitment to a single, impermeable boundary separating humans from nonhumans, in favour of tracing the specific ways in which collectives, made up of human-nonhuman alliances, operate and elicit responses. Latour focuses above all on cooperation, co-creation and construction with an entity, as opposed to its mere capacity for logos. He extends the capacity to speak, to act, to intend to nonhumans, instead of withholding such facilities from them. This allows him to widen the domain of politics and political actors, broadening that which was too narrowly conceptualized in Rancière's work. Latour avoids a classification of entities according to criteria of genera and species, based on an essence and capacity, as he turns to practice-based categories of actants and modes. Speech, as Latour observes, is 'a property of the whole setting in which very heterogeneous elements have been gathered and connected' (WAP 376). These settings produce interests and subjects that have the potential to radically reconfigure the initial conditions of possibility and, in turn, create new subjects and new settings. They can modify the internal distribution of functions, rearrange the actants' roles and transform obstacles into means of realization that in turn produce new relations, new entities and new settings. An interaction between an actant and a setting in this framework produces a type of 'associated milieu', to use Gilbert Simondon's term (Simondon[1958] 2017), that enables an articulation of a hybrid, human-nonhuman logos.

Articulation reframes logos: it invents an alternative means to deliberate what is just and what is unjust, what is harmful and what is useful, what is good and what is evil. It includes nonhumans in this deliberation, instead of leaving these questions only to entities that possess logos. Articulation, moreover, effectively resists the tendency towards pure abstraction. Questions of value, ethics and

20 This is true of AIME and late Latour rather than his earlier work in ANT. In the latter, it could be convincingly argued, there is little differentiation between humans and nonhumans. 
politics are reframed in such a way that it is very difficult to detach them from specific settings, practices and temporalities. A transhistorical enquiry of 'what is to be done?', 'what is being?', 'what is truth?' that would try to abstract from these concrete settings is constantly undercut (cf. Stengers 2010, pp. 180-88). Latour reflects on how nonhumans reconfigure the very frameworks that are set up to study them, how they impose specific obligations on human-nonhuman collectives, and how they catalyse inventions (cf. WAP). He proposes a wide variety of protocols to co-create articulation with nonhumans, allowing them to reconfigure the distribution of the sensible in order to render previously mute nonhuman entities, finally, intelligible. With close attention to such mechanisms of visibilization, and the ways in which this process transforms the status quo, it becomes clear that Latour is not quite as distant from Rancière as one might first think.

Funding: This project has received funding from the European Union's Horizon 2020 research and innovation programme under the Marie Skłodowska-Curie grant agreement No 754513 and The Aarhus University Research Foundation.

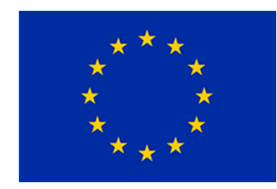

Conflicts of Interest: The author declares no conflict of interest.

\section{References}

Bennett, Jane. 2010. Vibrant Matter: A Political Ecology of Things. Durham: Duke University Press.

Boddice, Rob. 2011. Anthropocentrism: Humans, Animals, Environments. Leiden: Brill.

Braidotti, Rosi. 2013. The Posthuman. Cambridge: Polity Press.

Braidotti, Rosi. 2018. A Theoretical Framework for the Critical Posthumanities. Theory, Culture E Society 36: 31-61.

Braidotti, Rosi. 2019. Transversal Posthumanities. Philosophy Today 63: 1181-95. [CrossRef]

Buchanan, Brett, Matthew Chrulew, and Jeffrey Bussolini. 2015. Vinciane Despret. Angelaki: Philosophical Ethology II-Vinciane Despret 20: 2. [CrossRef]

Cavalieri, Paola, ed. 2016. Philosophy and the Politics of Animal Liberation. New York: Palgrave Macmillan.

Cavarero, Adriana. 2016. Inclinations: A Critique of Rectitude. Translated by Amanda Minervini, and Adam Sitze. Stanford: Stanford University Press.

Chambers, Samuel Allen. 2013. The Lessons of Rancière. New York: Oxford University Press.

Colebrook, Claire. 2014. Death of the Posthuman. Ann Arbor: Open Humanities Press.

Coole, Diana, and Samantha Frost, eds. 2010. New Materialisms: Ontology, Agency, and Politics. Durham: Duke University Press.

Crist, Eileen, and Helen Kopnina. 2014. Unsettling Anthropocentrism. Dialectical Anthropology 38: 387-96. [CrossRef] Despret, Vinciane. 1996. Naissance d'une théorie éthologique: la danse du cratérope écaillé. Le Plessis-Robinson: Synthélabo. Despret, Vinciane. 2004. The Body We Care for: Figures of Anthropo-Zoo-Genesis. Body E Society 10: 111-34.

Despret, Vinciane. 2005. Sheep Do Have Opinions. In Making Things Public: Atmospheres of Democracy. Edited by Bruno Latour and Peter Weibel. Cambridge and London: MIT, pp. 360-68.

Despret, Vinciane. 2008. The Becomings of Subjectivity in Animal Worlds. Subjectivity 23: 123-39. [CrossRef]

Despret, Vinciane. 2013. 'From Secret Agents to Interagency'. History and Theory 52: 29-44. [CrossRef]

Despret, Vinciane. 2016. What Would Animals Say if We Asked the Right Questions? Translated by Brett Buchanan. Minneapolis and London: University of Minnesota Press.

Despret, Vinciane. 2018. Out of The Books: Field Philosophy. Parallax 24: 416-28. [CrossRef]

Despret, Vinciane. 2019. Habiter en Oiseau. Arles: Actes Sud.

Dolphijn, Rick, and Iris van der Tuin, eds. 2012. New Materialism: Interviews and Cartographies. Ann Arbor: Open Humanities Press.

Greimas, Algirdas Julien. 1990. Narrative Semiotics and Cognitive Discourses. Translated by Paul Perron, and Frank H. Collins. London: Printer Publishers. 
Greimas, Algirdas Julien, and Joseph Courtés. 1979. Sémiotique. Dictionnaire raisonné de la théorie du langage. Paris: Hachette.

Gruen, Lori. 2015. Entangled Empathy: An Alternative Ethic for Our Relationships with Animals. New York: Lantern Books.

Haraway, Donna J. 2008. When Species Meet. Minneapolis and London: University of Minnesota Press.

Hayles, N. Katherine. 1999. How We Became Posthuman Virtual Bodies in Cybernetics, Literature, and Informatics. Chicago: University of Chicago Press.

Hornborg, Alf. 2017. Artifacts Have Consequences, Not Agency: Toward a Critical Theory of Global Environmental History. European Journal of Social Theory 20: 95-110. [CrossRef]

Janicka, Iwona. 2017. Theorizing Contemporary Anarchism. Solidarity, Mimesis and Radical Social Change. London and New York: Bloomsbury Academic.

Janicka, Iwona. 2020. Nonhuman Politics and its Practices. In The Bloomsbury Handbook of Posthumanism. Edited by Jacob Wamberg and Mads Rosendahl Thomsen. London and New York: Bloomsbury Academic, pp. $129-40$.

Kidner, David W. 2014. Why “Anthropocentrism" Is Not Anthropocentric. Dialectical Anthropology 38: 465-80. [CrossRef]

Kopnina, Helen, Haydn Washington, Bron Taylor, and John Piccolo. 2018. Anthropocentrism: More than Just a Misunderstood Problem. Journal of Agricultural and Environmental Ethics 31: 109-27. [CrossRef]

Latour, Bruno. 1993. We Have Never Been Modern. Translated by Catherine Porter. Cambridge: Harvard University Press.

Latour, Bruno. 1999. Pandora's Hope. Essays on the Reality of Science Studies. Cambridge and London: Harvard University Press.

Latour, Bruno. 2000. A Well-Articulated Primatology: Reflexions of a Fellow-Traveller. In Primate Encounters: Models of Science, Gender, and Society. Edited by Shirley Strum and Linda Fedigan. Chicago and London: University of Chicago Press, pp. 358-81.

Latour, Bruno. 2004. Politics of Nature: How to Bring the Sciences into Democracy. Translated by Catherine Porter. Cambridge and London: Harvard University Press.

Latour, Bruno. 2005. Reassembling the Social. An Introduction to Actor-Network-Theory. Oxford and New York: Oxford University Press.

Latour, Bruno. 2006. 'Des sujets récalcitrants'. In Chroniques d'un amateur de sciences. Paris: Presses des Mines. First published 1997. [CrossRef]

Latour, Bruno. 2007. Turning Around Politics: A Note on Gerard de Vries' Paper. Social Studies of Science 37: 811-20. [CrossRef]

Latour, Bruno. 2010. On the Modern Cult of the Factish Gods. Translated by Catherine Porter, and Heather MacLean. Durham and London: Duke University Press.

Latour, Bruno. 2012. Biographie d'une enquête. À propos d'un livre sur les modes d'existence. Archives de Philosophie 4: 549-66. [CrossRef]

Latour, Bruno. 2013a. An Inquiry into Modes of Existence: An Anthropology of the Moderns. Translated by Catherine Porter. Cambridge: Harvard University Press.

Latour, Bruno. 2013b. Articulation. An Inquiry into Modes of Existence. Available online: http:/modesofexistence. org/inquiry/?lang=en\#a=SEARCH\&s=0\&q=articulation (accessed on 30 June 2020).

Latour, Bruno. 2014. Can We Use Semiotics as a Metalanguage for Capturing the Differences between the Modes of Existence? Semiotics Seminar: AIME and Semiotics. 7 May 2014. Paris. Available online: http://modesofexistence.org/seminaire-semiotique-eme-et-la-semiotique/ (accessed on 31 January 2020).

Latour, Bruno. 2017. Facing Gaia: Eight Lectures on the New Climatic Regime. Translated by Catherine Porter. Cambridge and Malden: Polity Press.

Latour, Bruno. 2018. Down to Earth: Politics in the New Climatic Regime. E-Book Edition. Cambridge and Malden: Polity Press.

Latour, Bruno, J. V. P. Stein, and Nikolaj Schultz. 2019. A Conversation with Bruno Latour and Nikolaj Schultz: Reassembling the Geo-Social. Theory, Culture E Society 36: 215-30. [CrossRef]

Marchesini, Roberto. 2015. Against Anthropocentrism. Non-Human Otherness and the Post-Human Project. NanoEthics 9: 75-84. [CrossRef]

Massumi, Brian. 1998. Sensing the Virtual, Building the Insensible. Architectural Design 68: 16-24.

Massumi, Brian. 2002. Parables for the Virtual: Movement, Affect, Sensation. Durham: Duke University Press. 
Massumi, Brian. 2014. What Animals Teach Us about Politics. Durham: Duke University Press.

Oliver, Kelly. 2007. Stopping the Anthropological Machine: Agamben with Heidegger and Merleau-Ponty. Phaenex 2: 1-23. [CrossRef]

Perron, Paul. 1988. 'Introduction' in Algirdas Julien Greimas. In Maupassant. The Semiotics of Text: Practical Exercises. Translated by Paul Perron. Amsterdam: J. Benjamins, pp. xv-xxii.

Plumwood, Val. 2002. Environmental Culture: The Ecological Crisis of Reason. London: Routledge.

Porcher, Jocelyne. 2017. The Ethics of Animal Labor: A Collaborative Utopia. Cham: Palgrave Macmillan.

Probyn-Rapsey, Fiona. 2018. Anthropocentrism. In Critical Terms for Animal Studies. Edited by Lori Gruen. Chicago and London: University of Chicago Press, pp. 47-63.

Rancière, Jacques. 1999. Disagreement. Politics and Philosophy. Translated by Julie Rose. London and Minneapolis: University of Minnesota Press.

Rancière, Jacques. 2007. The Future of the Image. Translated by Gregory Elliott. London and New York: Verso.

Rancière, Jacques. 2010a. The Aesthetic Unconscious. Translated by Debra Keats, and James Swenson. Cambridge and Malden: Polity.

Rancière, Jacques. 2010b. Dissensus: On Politics and Aesthetics. Edited and Translated by Steve Corcoran. London and New York: Continuum.

Rancière, Jacques. 2011. The Politics of Literature. Translated by Julie Rose. Cambridge and Malden: Polity.

Rancière, Jacques. 2013. The Politics of Aesthetics. Edited and Translated by Gabriel Rockhill. London and New York: Bloomsbury Academic.

Rancière, Jacques. 2016. The Method of Equality: Interviews with Laurent Jeanpierre and Dork Zabunyan. Translated by Julie Rose. Cambridge and Malden: Polity.

Rancière, Jacques. 2017. Les Bords de la fiction. Paris: Seuil.

Rancière, Jacques, and Adnen Jdey. 2018. La Méthode de la scène. Paris: Lignes.

Schultz, Nikolaj C. B., and Bruno Latour. 2020. Cosmology and Class: An Interview with Bruno Latour by Nikolaj Schultz. Critical Inquiry. January 13. Available online: https://critinq.wordpress.com/2020/01/13/cosmologyand-class-an-interview-with-bruno-latour-by-nikolaj-schultz/ (accessed on 30 June 2020).

Simondon, Gilbert. 2017. On the Mode of Existence of Technical Objects. Translated by Cécile Malaspina, and John Rogove. Minneapolis: Univocal Publishing. First published 1958.

Sloterdijk, Peter. 2011. Spheres. Volume I: Bubbles. Microspherology. Translated by Wieland Hoban. Los Angeles: Semiotext(e).

Sloterdijk, Peter. 2014. Spheres. Volume II: Globes. Microspherology. Translated by Wieland Hoban. Los Angeles: Semiotext(e).

Sloterdijk, Peter. 2016. Spheres. Volume III: Foams. Plural Spherology. Translated by Wieland Hoban. Los Angeles: Semiotext(e).

Souriau, Etienne. 2015. The Different Modes of Existence. Translated by Erik Beranek, and Tim Howles. Minneapolis, MN: Univocal.

Stengers, Isabelle. 2010. Cosmopolitics. Translated by Robert Bononno. Minneapolis and London: University of Minnesota Press.

Stengers, Isabelle, and Bruno Latour. 2015. 'The Sphinx of the Work' in Etienne Souriau. In The Different Modes of Existence. Translated by Erik Beranek, and Tim Howles. Minneapolis: Univocal, pp. 11-94.

Van der Tuin, Iris, and Rick Dolphijn. 2010. The Transversality of New Materialism. Women: A Cultural Review 21: 153-71. [CrossRef]

Publisher's Note: MDPI stays neutral with regard to jurisdictional claims in published maps and institutional affiliations.

(C) 2020 by the author. Licensee MDPI, Basel, Switzerland. This article is an open access article distributed under the terms and conditions of the Creative Commons Attribution (CC BY) license (http://creativecommons.org/licenses/by/4.0/). 